\title{
Optimization of a Pressing Diagram in OSB Pressing
}

\section{Optimizacija dijagrama prešanja pri prešanju OSB ploča}

\author{
Original scientific paper • Izvorni znanstveni rad \\ Received-prispjelo: 27. 9. 2010. \\ Accepted-prihvaćeno: 25. 2. 2011. \\ UDK: $630 * 863.21$ \\ doi:10.5552/drind.2011.1032
}

\begin{abstract}
This paper summarizes the results of a pressing diagram optimization based on changes in pressure, temperature and distance between frames of a continuous press during Oriented Strand Boards (OSB) pressing. Tests of selected mechanical properties were carried out on OSB/3 boards with a nominal thickness of $18 \mathrm{~mm}$ - a basic type with urea-formaldehyd (UF) glue in surface layers and isocyanate glue (PMDI) in the central layer and further an ECO type with PMDI glue in all layers produced by a prominent manufacturer of OSB boards in the Czech Republic. OSB/3 boards are intended for structural purposes for use in wet environments. Changes in the pressing diagram were carried out at the stage of "press opening", which significantly affects mechanical and physical properties of OSB boards. In order to be able to compare the effects of changes in the pressing curve, the same setting of production parameters was used with all tested boards. The results of laboratory tests were compared with the values given in the ČSN EN 300 Standard. Optimization of the pressing process ranks among the most effective measures to increase the quality of particle boards at zero or minimum costs. The control of production processes is increasingly perfect thanks to the development of electronics, control and computer technology. At present, not only in our country but also worldwide, marked development of wooden constructions occurs thanks to the development of new types of wood-based composite materials and to the development of technologies in building industry. OSB boards are an important representative of wood-based composite materials for wooden constructions. As compared to natural material, OSB boards show a homogenous structure not including natural defects typical of solid wood. From the point of view of physical and mechanical properties, OSB boards are of orthotropic character.
\end{abstract}

Keywords: OSB, pressing, technical properties, isocyanate glue (PMDI), urea-formaldehyd glue (UF)

SAŽETAK • U radu se prikazuju rezultati optimizacije dijagrama prešanja utemeljeni na promjenama tlaka, temperature i udaljenosti između okvira kontinuirane preše pri prešanju ploča s usmjerenim iverjem - OSB ploča (Oriented Strand Boards). Mehanička svojstva mjerena su na pločama OSB/3, nominalne debljine $18 \mathrm{~mm}$, na osnovnom tipu ploče s urea-formaldehidnim (UF) ljepilom u vanjskom sloju i izocijanatnim (PMDI) ljepilom u središnjem sloju te na ekološkom tipu ploče s PMDI ljepilom u svim slojevima, koje je proizveo priznati proizvođač OSB ploča u Republici Češkoj. OSB/3 ploče upotrebljavaju se za konstrukcijske svrhe u vlažnom okruženju. Promjene u dijagramu prešanja napravljene su u fazi “otvaranja prě̌e”, koja bitno utječe na mehanička i fizikalna svojstva OSB ploča. Da bi se mogli uspoređivati učinci promjena u dijagramu prešanja, za sve su uzorke ploča upotrijebljeni jednaki parametri proizvodnje. Rezultati laboratorijskih mjerenja uspoređeni su s podacima iz norme ČSN EN 300. Optimizacija procesa prešanja pripada najučinkovitijim načinima povećanja kvalitete ploča iverica uz male troškove ili bez ikakvih izdataka. Kontrola procesa proizvodnje postala je bitno bolja zahvaljujući razvoju elektronike, kontrolne i računalne tehnologije. Trenutačno se u svijetu bilježi znatan porast upotrebe kon-

\footnotetext{
${ }^{1}$ The authors are assistant professors at the Faculty of Forestry and Wood Technology, Mendel University, Brno, Czech Republic.

${ }^{1}$ Autori su docenti Fakulteta Šumarstva i drvne tehnologije Mendelova sveučilišta u Brnu, Republika Češka.
} 
strukcijskog drva zahvaljujući razvoju novih kompozitnih materijala od drva i novih tehnologija građenja. OSB ploče važan su predstavnik kompozitnih materijala za drvene konstrukcije. U usporedbi s prirodnim materijalima, prednost OSB ploča je to što imaju homogenu strukturu bez grě̌aka koje su tipične za masivno drvo. Sa stajališta fizikalnih i mehaničkih svojstava, OSB ploče su ortotropan materijal.

Ključne riječi: OSB ploče, tehnička svojstva, izocijanatno ljepilo (PMDI), urea-formaldehidno ljepilo (UF)

\section{INTRODUCTION}

\section{UVOD}

Hot pressing is considered to be the most important operation in the whole process of particleboard production. The aim of pressing is to compress particle mats to a required thickness and also to densify and fix the chips in this stage through glue hardening. The particle mat represents a complicated system of wood particles, water and chemical admixtures, which is fed into the wedged entrance of a hot continuous press where it is gradually thickened to a nominal thickness through the pressure of steel pressing belts and, at the same time, heated by the belts to the required reaction temperature (Kühne and Belimow, 1978). After passing all stages of the pressing process and after partial cooling and reducing the working pressure in the last part of the continuous press, the pressed material leaves the press (Hrázský and Král, 2007).

Immediately after putting the chip mat into the press, surface layers of the mat meet with hot pressing belts of the continuous press and thus intensive exchange occurs between the belts and the chip mat. This intensity depends on the temperature gradient whose size is continuously changed in the hot pressing process because the chip mat temperature changes during this procedure. The process of the heat transfer occurs in two directions, namely perpendicular to the board plane and in parallel with the board plane. The transfer of heat is realized through heat conductivity, convection and heat emission (radiation). The heat conductivity of a chip mat is calculated from the heat conductivity of wood particles, water, air and chemical admixtures. The heat transfer through the material originates from the flow of water vapour and diffusion of moisture contained in the chip mat. (Bolton et al, 1989). In consequence of the unevenly distributed moisture in the chip mat and moisture differences between the chip mat and surroundings, two moisture gradients occur, thereby generating moisture diffusion. The first moisture gradient becomes particularly evident perpendicular to the mat plane towards the central layer of the mat. After drying-up the upper chip layer, the direction of this gradient changes by $180^{\circ}$, simultaneously with the change of the pressure gradient direction. The second moisture gradient occurs in parallel with the mat plane toward the surroundings. The transfer of heat by the flow of water vapours and gases is particularly intensive. Their flow is caused by producing inner pressure. At the contact of hot pressing belts (about $220^{\circ} \mathrm{C}$ ) with the chip mat, intensive formation of vapours occurs first in the surface zone. At the same time, air contained in the surface layer is heated, which results in increasing the volume. Therefore, corre- sponding overpressure is generated in the mat surface zone, which results in the development of two pressure gradients. One pressure gradient occurs in the direction perpendicular to the chip mat plane. At the beginning of pressing, its direction first takes place towards the inner layers of the mat. After heating the central layer to a temperature of about $100{ }^{\circ} \mathrm{C}$, the inner pressure is generated in this area by vapours formed from the existing moisture, which will result in the change of the direction of pressure gradient by $180^{\circ}$. Through this pressure in the chip mat, the second pressure gradient is created, which functions in parallel with the mat plane towards the surroundings. The time effect of pressure and temperature gradients results in the process of material transfer in the hot pressing process. Heat, material and pressure processes determine to a great extent the quality of products and the production line productivity. The compressing process in the press is controlled from outside through temperature, pressure and the speed of the maximum working pressure start. The higher the temperature the higher the relative resistance to the compression of a chip mat not yet heated (Deppe and Ernst, 1991).

The pressing temperature will always play an important - crucial role. The pressing cycle principally consists of three stages: time $t_{1}-$ until reaching the nominal thickness of a pressed material, time $t_{2}$ - effects of the maximum working pressure and the course of an actual board-formation process, $t_{3}$ - ventilation, cooling, pressure reduction and leaving the continuous press. The course of the pressing process is programmed in practice. If pressure and time are selected as control values ( $p, t_{1}$ - program), the speed of reaching the nominal thickness and maximum working pressure depends on the resistance of the pressed material to pressing (compression). If travel and pressure are the starting basis ( $s, p$-program), then resistance to pressing (compression) is affected by time $\mathrm{t}_{1}$ and in a program the distance from the entry point, time ( $s, t$ - program), is the third control element, i.e. pressure in pistons (hydraulic pressure). External control values, namely pressure $(p)$, piston speed $(v)$ and time $(t)$ are measurable and adjustable; they can be set within certain limits. As the inner resistance to pressing (compression) is unknown and measurable with difficulties, only two external control values are always programmable. In the course of the development of particleboards, both pressing temperature and working pressure were increased (Štefka, 1999).

There were expectations that rapid achievement of maximum pressing pressure will be avoided by using low-quality surface area, but they were not always satisfactorily met. 
Table 1 Adjusted manufacturing parameters for $\mathrm{OSB} / 3,18 \mathrm{~mm}$ nominal thickness

Tablica 1. Postavljeni proizvodni parametri za ploče OSB/3 nominalne debljine $18 \mathrm{~mm}$

\begin{tabular}{|c|c|c|c|c|c|c|}
\hline \multirow{2}{*}{$\begin{array}{c}\text { Nominal } \\
\text { thickness } \\
\text { Nominalna } \\
\text { debljina } \\
\mathrm{mm}\end{array}$} & \multirow[t]{2}{*}{$\begin{array}{l}\text { Press factor } \\
\text { Faktor prešanja } \\
\text { s/mm }\end{array}$} & \multirow{2}{*}{$\begin{array}{l}\text { Calculating } \\
\text { density } \\
\text { Izračunana } \\
\text { gustoća } \mathrm{kg} / \mathrm{m}^{3}\end{array}$} & \multicolumn{2}{|c|}{$\begin{array}{l}\text { Amount of glue } \\
\text { Količina ljepila }\end{array}$} & \multicolumn{2}{|c|}{$\begin{array}{c}\text { Chips moisture content before } \\
\text { blending }\end{array}$} \\
\hline & & & $\begin{array}{c}\mathrm{UF}\left(\mathrm{SL}^{*}\right) \\
\%\end{array}$ & $\begin{array}{c}\text { PMDI (ML*) } \\
\%\end{array}$ & $\begin{array}{l}\text { SL } \\
\%\end{array}$ & $\begin{array}{l}\text { ML } \\
\%\end{array}$ \\
\hline 18.0 & 7.54 & 575 & 3.1 & 3.5 & 5.1 & 3.9 \\
\hline
\end{tabular}

*SL - surface layer / vanjski sloj; ML - middle layer / središnji sloj

Table 2 Adjusted manufacturing parameters for OSB/3 ECO, $18 \mathrm{~mm}$ nominal thickness

Tablica 2. Postavljeni proizvodni parametri za ekološke ploče OSB/3 ECO nominalne debljine $18 \mathrm{~mm}$

\begin{tabular}{|c|c|c|c|c|c|c|}
\hline $\begin{array}{c}\text { Nominal } \\
\text { thickness } \\
\text { Nominalna } \\
\text { debljina }\end{array}$ & $\begin{array}{c}\text { Press factor } \\
\text { Faktor prešanja } \\
\mathrm{s} / \mathrm{mm}\end{array}$ & $\begin{array}{c}\text { Calculating } \\
\text { density } \\
\text { Izračunana } \\
\text { gustoća }\end{array}$ & \multicolumn{2}{|c|}{$\begin{array}{c}\text { Amount of glue } \\
\text { Količina ljepila }\end{array}$} & \multicolumn{2}{|c|}{$\begin{array}{c}\text { Chips moisture content } \\
\text { before blending }\end{array}$} \\
\cline { 4 - 7 } & & $\begin{array}{c}\text { PMDI (SL*) } \\
\text { Sadržaj vode u iverju prije miješanja }\end{array}$ & $\begin{array}{c}\text { PMDI (ML*) } \\
\%\end{array}$ & $\begin{array}{c}\text { SL } \\
\%\end{array}$ & $\begin{array}{c}\text { ML } \\
\%\end{array}$ \\
\hline 18.0 & 7.54 & 575 & 3.1 & 3.5 & 5.1 & 3.9 \\
\hline
\end{tabular}

*SL - surface layer / vanjski sloj; ML - middle layer / središnji sloj

Štefka (2007) supposed that residual stress was caused by the pressure of vapours originating from moisture contained in the chip mat. This fact can cause not only larger or smaller springing of the board, but at excessive moisture, also ripping of the board. Therefore, the pressing process has to be carried out in such a way not only to achieve the optimum construction of particle boards from the aspect of the density profile but also the required strength of bonding the chips, which is, as a matter of fact, the basic condition of good properties of particleboards.

The aim of this paper was to optimize the pressing diagram on the basis of measuring changes of pressure and temperature and distance between frames of a continuous press in the board in OSB pressing. Changes of the pressing curve were carried out at the stage of "press opening" because these changes substantially affected physical and mechanical properties of OSB boards.

\section{MATERIAL AND METHODS 2. MATERIJAL I METODE}

Pressing the OSB boards was carried out using the Dieffenbacher CPS 280-53/OSB continuous press, an OSB production line of a prominent Czech manufacturer of board composite materials in the Czech Republic. The pressing process proceeded between two steel belts running along a fixed pressing line. This line consists of 41 identical pressing frames. Furthermore, the press consists of an upper and lower heating plate. The lower plate is supported by 160 hydraulic cylinders, situated on lower beams. The lower heating plate moves up by means of hydraulics producing pressure on the chip mat through roller chains and steel belts. Warming the heating plates is performed by thermo oil. In the process of pressing in a continuous press, the following pressure and temperature phases are distinguished:

Pressing phase Temperature, ${ }^{\circ} \mathrm{C}$ Specific pressure, $\mathrm{N} / \mathrm{mm}^{2}$

1- Input $\quad 220-225 \quad 3.0$

$2-\quad 215-230 \quad 1.6$

3- Centre $\quad 215-225 \quad 1.7$

4- $205-215 \quad 0.8$

5- Output $\quad 200-180 \quad 0.05$
Setting the production parameters of the OSB line:

The course of a pressing diagram particularly affects the bending strength (MOR), modulus of elasticity in bending (MOE) and most of all tensile strength perpendicular to the board plane. OSB boards sampled for tests of the OSB mechanical properties were glued in $1.1-1.3$ variants by using UF glue in surface layers and by PMDI glue in the central layer (Tab. 1). In variants $2.1-2.3$, the PMDI glue is used both for surface and central layers (Tab. 2). Requirements for boards of the OSB/3 technical class are determined by the ČSN EN 300 Standard. Test procedures to determine the bending strength in both axes are described in the ČSN EN 310 Standard and a test procedure to determine the tensile strength perpendicular to the board plane is described in the ČSN EN 319 Standard.

$\mathrm{OSB} / 3$ boards within thickness ranging between 18 and $25 \mathrm{~mm}$ have to fulfil the following requirements according to the ČSN EN 300 Standard - see Tab. 3.

In the manufacture of experimental OSB boards, for each variant of the pressing diagram three trial boards were sampled at the stage of "press opening" and necessary test specimens were cut from the boards according to the cutting plan (Fig. 1). At the end of pressing (all variants), the following tracks were selected: in variants 1.1 and 2.1 very fast "press opening" (i.e. larger distances in setting gaps between frames and larger differences in pressure between particular frames of the press - see Tabs. 4 and 7), in variants 1.2 and 2.2 gradual "press opening" (i.e. smaller differences between frame distances and smaller differences in pressure between particular frames) - see Tabs. 5 and 8 and in variants 1.3 and 2.3 very gradual "press opening" (i.e. small differences between distances of frames and small differences in pressure between particular frames of the press) - see Tabs. 6 and 9 .

Test specimens were cut from sampled experimental OSB boards of particular variants, and tests were carried out of selected mechanical properties. Dimensions of test specimens are determined by the ČSN EN 325 Standard. To obtain test specimens, the manufacturer plan of cutting (sawing) was used (Fig. 1). 
Table 3 Requirements related to OSB/3 according to ČSN EN 300

Tablica 3. Zahtjevi za OSB ploče prema ČSN EN 300

\begin{tabular}{|c|c|c|c|c|c|}
\hline \multirow{3}{*}{$\begin{array}{c}\text { OSB } / 3 \\
\text { Properties / Svojstvo }\end{array}$} & \multirow{3}{*}{$\begin{array}{l}\text { Standard } \\
\text { Norma }\end{array}$} & \multirow{3}{*}{$\begin{array}{c}\text { Unit } \\
\text { Jedinica }\end{array}$} & \multicolumn{3}{|c|}{ Requirements / Zahtjevi } \\
\hline & & & \multicolumn{3}{|c|}{$\begin{array}{c}\text { Range of thickness, mm (nominal values) } \\
\text { Raspon nominalnih debljina, } \mathrm{mm}\end{array}$} \\
\hline & & & 6 to 10 & $>10$ to $<18$ & 18 to 25 \\
\hline MOR \| & ČSN EN 310 & $\mathrm{~N} / \mathrm{mm}^{2}$ & 22 & 20 & 18 \\
\hline MOR $\perp$ & ČSN EN 310 & $\mathrm{~N} / \mathrm{mm}^{2}$ & 11 & 10 & 9 \\
\hline MOE & CSN EN 310 & $\mathrm{~N} / \mathrm{mm}^{2}$ & 3500 & 3500 & 3500 \\
\hline $\mathrm{MOE} \perp$ & ČSN EN 310 & $\mathrm{~N} / \mathrm{mm}^{2}$ & 1400 & 1400 & 1400 \\
\hline$\sigma_{t \perp}$ & ČSN EN 319 & $\mathrm{~N} / \mathrm{mm}^{2}$ & 0.34 & 0.32 & 0.30 \\
\hline Swelling / Bubrenje & ČSN EN 317 & $\%$ & 15 & 15 & 15 \\
\hline
\end{tabular}

Legend / Legenda: MOR - Bending strength / savojna čvrstoća; MOE - Modulus of elasticity / modul elastičnosti; $\sigma_{\mathrm{t}}$ - Tensile strength perpendicular / vlačna čvrstoća okomito

Table 4 Variant 1.1 - Optimization of press diagram - „very fast press opening“

Tablica 4. Varijanta 1.1 - optimizacija dijagrama prešanja - „vrlo brzo otvaranje preše“

\begin{tabular}{|l|c|c|c|c|c|c|}
\hline $\begin{array}{l}\text { OSB/3 - surface layer: UF resin / vanjski sloj: UF ljepilo } \\
\text { middle layer: PMDI resin / središnji sloj: PMDI ljepilo }\end{array}$ & $\begin{array}{c}\text { Frame } \\
\text { No. 36 }\end{array}$ & $\begin{array}{c}\text { Frame } \\
\text { No. 37 }\end{array}$ & $\begin{array}{c}\text { Frame } \\
\text { No. 38 }\end{array}$ & $\begin{array}{c}\text { Frame } \\
\text { No. 39 }\end{array}$ & $\begin{array}{c}\text { Frame } \\
\text { No. } 40\end{array}$ & $\begin{array}{c}\text { Frame } \\
\text { No. } 41\end{array}$ \\
\hline Working pressure, N/mm $/$ Radni tlak, N/mm & 0.80 & 0.70 & 0.60 & 0.50 & 0.20 & 0.05 \\
\hline Pressing temperature, ${ }^{\circ}$ C / Temperatura prešanja, ${ }^{\circ}$ C & 205 & 200 & 195 & 190 & 185 & 180 \\
\hline $\begin{array}{l}\text { Distance between press frame, mm } \\
\text { Udaljenost između okvira preše, } \mathrm{mm}\end{array}$ & 17.8 & 17.9 & 18.2 & 18.5 & 19.25 & 21.0 \\
\hline
\end{tabular}

Table 5 Variant 1.2 - Optimization of press diagram - ,gradual press opennig“

Tablica 5. Varijanta 1.2 - optimizacija dijagrama prešanja - ,postupno otvaranje preše“

\begin{tabular}{|c|c|c|c|c|c|c|}
\hline $\begin{array}{l}\text { OSB/3 - surface layer: UF resin / vanjski sloj: UF ljepilo } \\
\text { middle layer: PMDI resin / središnji sloj: PMDI ljepilo }\end{array}$ & $\begin{array}{l}\text { Frame } \\
\text { No. } 36\end{array}$ & $\begin{array}{l}\text { Frame } \\
\text { No. } 37\end{array}$ & $\begin{array}{l}\text { Frame } \\
\text { No. } 38\end{array}$ & $\begin{array}{l}\text { Frame } \\
\text { No. } 39\end{array}$ & $\begin{array}{l}\text { Frame } \\
\text { No. } 40\end{array}$ & $\begin{array}{l}\text { Frame } \\
\text { No. } 41\end{array}$ \\
\hline Working pressure, $\mathrm{N} / \mathrm{mm}^{2} /$ Radni tlak, $\mathrm{N} / \mathrm{mm}^{2}$ & 0.80 & 0.75 & 0.70 & 0.65 & 0.30 & 0.05 \\
\hline Pressing temperature, ${ }^{\circ} \mathrm{C} /$ Temperatura prešanja, ${ }^{\circ} \mathrm{C}$ & 205 & 200 & 195 & 190 & 185 & 180 \\
\hline $\begin{array}{l}\text { Distance between press frame, } \mathrm{mm} \\
\text { Udaljenost između okvira preše, } \mathrm{mm}\end{array}$ & 17.8 & 17.9 & 18.0 & 18.25 & 18.75 & 19.5 \\
\hline
\end{tabular}

Table 6 Variant 1.3 - Optimization of press diagram - „very gradual press opening“

Tablica 6. Varijanta 1.3 - optimizacija dijagrama prešanja - „vrlo postupno otvaranje preše“

\begin{tabular}{|l|c|c|c|c|c|c|}
\hline $\begin{array}{l}\text { OSB/3 - surface layer: UF resin / vanjski sloj: UF ljepilo } \\
\text { middle layer: PMDI resin / središnji sloj: PMDI ljepilo }\end{array}$ & $\begin{array}{c}\text { Frame } \\
\text { No. 36 }\end{array}$ & $\begin{array}{c}\text { Frame } \\
\text { No. } 37\end{array}$ & $\begin{array}{c}\text { Frame } \\
\text { No. 38 }\end{array}$ & $\begin{array}{c}\text { Frame } \\
\text { No. } 39\end{array}$ & $\begin{array}{c}\text { Frame } \\
\text { No. } 40\end{array}$ & $\begin{array}{c}\text { Frame } \\
\text { No. } 41\end{array}$ \\
\hline Working pressure, N/mm / Radni tlak, N/mm $^{2}$ & 0.75 & 0.72 & 0.68 & 0.65 & 0.45 & 0.05 \\
\hline Pressing temperature, ${ }^{\circ} \mathrm{C} /$ Temperatura prešanja, ${ }^{\circ} \mathrm{C}$ & 205 & 200 & 195 & 190 & 185 & 180 \\
\hline $\begin{array}{l}\text { Distance between press frame, } \mathrm{mm} \\
\text { Udaljenost između okvira preše, } \mathrm{mm}\end{array}$ & 18.0 & 18.1 & 18.2 & 18.3 & 18.4 & 18.5 \\
\hline
\end{tabular}

Table 7 Variant 2.1 - Optimization of press diagram - „very fast press opening“

Tablica 7. Varijanta 2.1 - optimizacija dijagrama prešanja - „vrlo brzo otvaranje preše“

\begin{tabular}{|c|c|c|c|c|c|c|}
\hline $\begin{array}{r}\text { OSB/3 - } \text { surface layer: PMDI resin / vanjski sloj: PMDI ljepilo } \\
\text { middle layer: PMDI resin / središnji sloj: PMDI ljepilo }\end{array}$ & $\begin{array}{l}\text { Frame } \\
\text { No. } 36\end{array}$ & $\begin{array}{l}\text { Frame } \\
\text { No. } 37\end{array}$ & $\begin{array}{l}\text { Frame } \\
\text { No. } 38\end{array}$ & $\begin{array}{l}\text { Frame } \\
\text { No. } 39\end{array}$ & $\begin{array}{l}\text { Frame } \\
\text { No. } 40\end{array}$ & $\begin{array}{l}\text { Frame } \\
\text { No. } 41\end{array}$ \\
\hline Working pressure, $\mathrm{N} / \mathrm{mm}^{2} /$ Radni tlak, $\mathrm{N} / \mathrm{mm}^{2}$ & 0.80 & 0.70 & 0.60 & 0.50 & 0.20 & 0.05 \\
\hline Pressing temperature, ${ }^{\circ} \mathrm{C}$ Temperatura prešanja, ${ }^{\circ} \mathrm{C}$ & 205 & 200 & 195 & 190 & 185 & 180 \\
\hline $\begin{array}{l}\text { Distance between press frame, } \mathrm{mm} \\
\text { Udaljenost između okvira preše, } \mathrm{mm}\end{array}$ & 17.8 & 17.9 & 18.2 & 18.5 & 19.25 & 21.0 \\
\hline
\end{tabular}

Table 8 Variant 2.2 - Optimization of press diagram - ,gradual press opennig“

Tablica 8. Varijanta 2.2 - optimizacija dijagrama prešanja - „postupno otvaranje preše“

\begin{tabular}{|l|c|c|c|c|c|c|}
\hline $\begin{array}{l}\text { OSB/3 - surface layer: PMDI resin / vanjski sloj: PMDI ljepilo } \\
\text { middle layer: PMDI resin / središnji sloj: PMDI ljepilo }\end{array}$ & $\begin{array}{c}\text { Frame } \\
\text { No. 36 }\end{array}$ & $\begin{array}{c}\text { Frame } \\
\text { No. } 37\end{array}$ & $\begin{array}{c}\text { Frame } \\
\text { No. 38 }\end{array}$ & $\begin{array}{c}\text { Frame } \\
\text { No. } 39\end{array}$ & $\begin{array}{c}\text { Frame } \\
\text { No. } 40\end{array}$ & $\begin{array}{c}\text { Frame } \\
\text { No. } 41\end{array}$ \\
\hline Working pressure, N/mm $/$ Radni tlak, $^{2} \mathrm{~mm}^{2}$ & 0.80 & 0.75 & 0.70 & 0.65 & 0.30 & 0.05 \\
\hline Pressing temperature, ${ }^{\circ} \mathrm{C} /$ Temperatura prešanja, ${ }^{\circ} \mathrm{C}$ & 205 & 200 & 195 & 190 & 185 & 180 \\
\hline $\begin{array}{l}\text { Distance between press frame, mm } \\
\text { Udaljenost između okvira preše, } \mathrm{mm}\end{array}$ & 17.8 & 17.9 & 18.0 & 18.25 & 18.75 & 19.5 \\
\hline
\end{tabular}




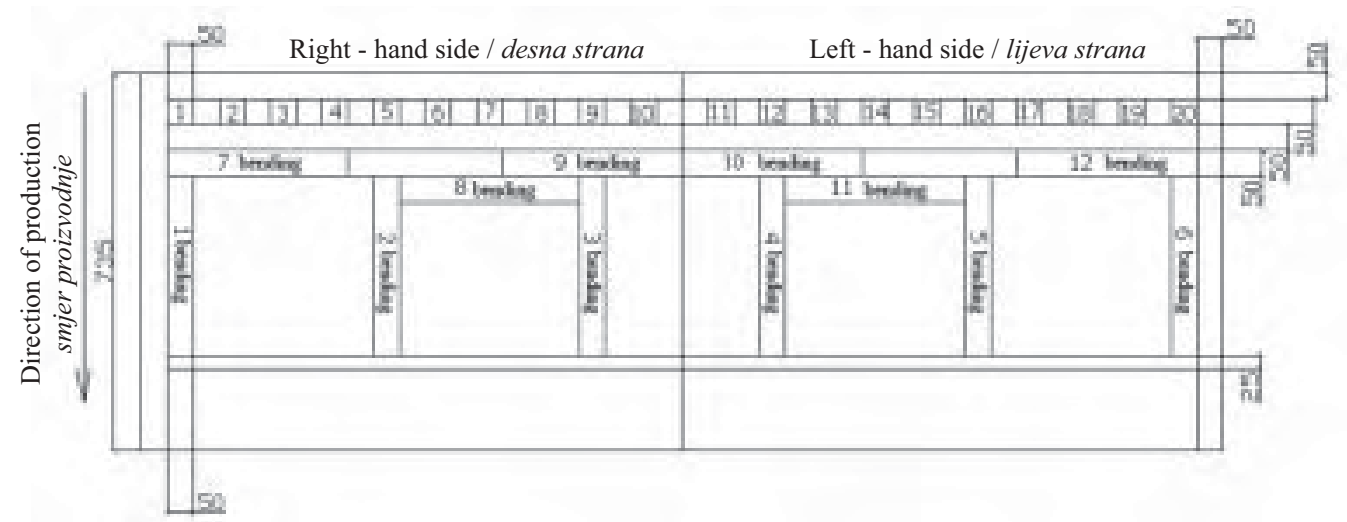

Figure 1 Cutting plan for sampling test specimens (1-20: tensile strength perpendicular to the board surface; 1-12 bending: MOR and MOE)

Slika 1. Plan rezanja za izradu uzoraka (1-20 uzorci za mjerenje vlačne čvrstoće okomito na površinu ploče; 1-12 uzorci za savijanje i mjerenje veličina MOR i MOE)

Table 9 Variant 2.3 - Optimization of press diagram - ,very gradual press opening“

Tablica 9. Varijanta 2.3 - optimizacija dijagrama prešanja - „vrlo postupno otvaranje preše“

\begin{tabular}{|c|c|c|c|c|c|c|}
\hline $\begin{array}{r}\text { OSB/3 - surface layer: PMDI resin / vanjski sloj: PMDI ljepilo } \\
\text { middle layer: PMDI resin / središnji sloj: PMDI ljepilo }\end{array}$ & $\begin{array}{l}\text { Frame } \\
\text { No. } 36\end{array}$ & $\begin{array}{l}\text { Frame } \\
\text { No. } 37\end{array}$ & $\begin{array}{l}\text { Frame } \\
\text { No. } 38\end{array}$ & $\begin{array}{l}\text { Frame } \\
\text { No. } 39\end{array}$ & $\begin{array}{l}\text { Frame } \\
\text { No. } 40\end{array}$ & $\begin{array}{l}\text { Frame } \\
\text { No. } 41\end{array}$ \\
\hline Working pressure, $\mathrm{N} / \mathrm{mm}^{2} /$ Radni tlak, $N / \mathrm{mm}^{2}$ & 0.75 & 0.72 & 0.68 & 0.65 & 0.45 & 0.05 \\
\hline Pressing temperature, ${ }^{\circ} \mathrm{C} /$ Temperatura prešanja,${ }^{\circ} \mathrm{C}$ & 205 & 200 & 195 & 190 & 185 & 180 \\
\hline $\begin{array}{l}\text { Distance between press frame, } \mathrm{mm} \\
\text { Udaljenost između okvira preše, } \mathrm{mm}\end{array}$ & 18.0 & 18.1 & 18.2 & 18.3 & 18.4 & 18.5 \\
\hline
\end{tabular}

\section{RESULTS AND DISCUSSION}

3. REZULTATI I RASPRAVA

Laboratory tests were carried out on $\mathrm{OSB} / 3$ and OSB/3 ECO of 18-mm nominal thickness. The actual average values of thickness of the OSB/3 variants $1.1-$ 1.3 and $\mathrm{OSB} / 3$ ECO variants $2.1-2.3$ are listed in Tabs. 10-11. The results of tests of mechanical properties are shown in Tabs. 12-17.

The actual average values of thickness of the OSB/3 1.1-1.3 and OSB/3 ECO variants 2.1-2.3 are listed in Tabs. 10-11. The values are lower than $18 \mathrm{~mm}$. Technical properties of OSB boards were, therefore, considered in the thickness category ranging between 10 and $18 \mathrm{~mm}$.

The measurement of density showed that at the set value of production density of $575 \mathrm{~kg} / \mathrm{m}^{3}$, the highest increase of mean density occurred in variants OSB ECO 2.1 and $2.2\left(580 \mathrm{~kg} / \mathrm{m}^{3}\right)$ and, on the contrary, the highest decline of mean density (below the set production value) was determined in variant OSB $1.2\left(574 \mathrm{~kg} / \mathrm{m}^{3}\right)$. The mean density of variant OSB 1.1 reached the set production density $\left(575 \mathrm{~kg} / \mathrm{m}^{3}\right)$. Hence, from the aspect of the density evaluation, this variant appears to be the most suitable. Based on the comparison between the requirements of the CSN EN 300 Standard and the measured values, the density of variants OSB and OSB ECO ranges within the set limits $\pm 15 \%$ according to the general requirements for particular types of OSB boards.

As for tensile strength perpendicular to the board plane, our measurements demonstrated that the highest decline of its mean value occurred in variant OSB 1.1 $\left(0.31 \mathrm{~N} / \mathrm{mm}^{2}\right)$. This value does not meet the requirements of the ČSN EN 300 Standard for OSB/3 (0.32 N/ $\mathrm{mm}^{2}$ ). The highest increase in the mean value of tensile strength perpendicular to the board plane occurred in Variant OSB $1.2\left(0.38 \mathrm{~N} / \mathrm{mm}^{2}\right)$ and the lowest increase in variants OSB ECO 2.1 and $2.2\left(0.35 \mathrm{~N} / \mathrm{mm}^{2}\right)$. In other variants all determined values of tensile strength perpen-

Table 10 Average thickness of OSB/3 for variants $1.1-1.3$

Tablica 10. Srednja vrijednost debljine OSB/3 za varijante 1.1-1.3.

\begin{tabular}{|l|c|c|c|c|c|c|c|c|c|c|c|c|}
\hline Thickness, mm / Debljina, $\mathrm{mm}$ & \multicolumn{6}{|c|}{ Variant 1.1 / Varijanta 1.1. } & \multicolumn{2}{|c|}{ Variant 1.2 / Varijanta 1.2. } & \multicolumn{3}{|c|}{ Variant 1.3 / Varijanta 1.3. } \\
\hline OSB No. & 1 & 2 & 3 & $\overline{\bar{x}}$ & 1 & 2 & 3 & $\overline{\bar{x}}$ & 1 & 2 & 3 & $\overline{\bar{x}}$ \\
\hline $\begin{array}{l}\text { Average value } \bar{x} \\
\text { Srednja vrijednost }\end{array}$ & 17,75 & 17,44 & 17,36 & 17.52 & 17.45 & 17.53 & 17.62 & 17.53 & 17.55 & 17.54 & 17.43 & 17.51 \\
\hline
\end{tabular}

Table 11 Average thickness of OSB/3 ECO for variants 2.1-2.3

Tablica 11. Srednja vrijednost debljine OSB/3 ECO za varijante 2.1-2.3.

\begin{tabular}{|l|c|c|c|c|c|c|c|c|c|c|c|c|}
\hline Thickness, mm / Debljina, $\mathrm{mm}$ & \multicolumn{6}{|c|}{ Variant 2.1 / Varijanta 1.1. } & \multicolumn{2}{|c|}{ Variant 2.2 / Varijanta 1.2. } & \multicolumn{3}{|c|}{ Variant 2.3 / Varijanta 1.3. } \\
\hline OSB No. & 1 & 2 & 3 & $\overline{\bar{x}}$ & 1 & 2 & 3 & $\overline{\bar{x}}$ & 1 & 2 & 3 & $\overline{\bar{x}}$ \\
\hline $\begin{array}{l}\text { Average value } \bar{x} \\
\text { Srednja vrijednost }\end{array}$ & 17,48 & 17,24 & 17,48 & 17.52 & 17.66 & 17.19 & 17.58 & 17.48 & 17.40 & 17.45 & 17.58 & 17.48 \\
\hline
\end{tabular}


Table 12 Statistical evaluation for variant 1.1, OSB/3, $18 \mathrm{~mm}$ nominal thickness

Tablica 12. Statistička procjena rezultata za varijantu 1.1, OSB/3 nominalne debljine $18 \mathrm{~mm}$

\begin{tabular}{|c|c|c|c|c|c|c|}
\hline $\begin{array}{l}\text { Variant 1.1 / Varijanta 1.1. } \\
\text { High-speed press opening } \\
\text { Vrlo brzo otvaranje prě̌e }\end{array}$ & $\begin{array}{l}\text { Density } \\
\text { Gustoća } \\
\mathrm{kg} / \mathrm{m}^{3}\end{array}$ & $\begin{array}{c}\boldsymbol{\sigma}_{\mathbf{t}^{\perp}} \\
\mathrm{N} / \mathrm{mm}^{2}\end{array}$ & $\begin{array}{l}\text { MOR } \| \\
\mathrm{N} / \mathrm{mm}^{2}\end{array}$ & $\begin{array}{l}\text { MOE } \| \\
\mathrm{N} / \mathrm{mm}^{2}\end{array}$ & $\begin{array}{l}\text { MOR } \perp \\
\mathrm{N} / \mathrm{mm}^{2}\end{array}$ & $\begin{array}{l}\text { MOE } \perp \\
\mathrm{N} / \mathrm{mm}^{2}\end{array}$ \\
\hline $\begin{array}{l}\text { OSB No.1 } \\
\text { Average value within the board } \bar{x}_{j} \\
\text { Srednja vrijednost za ploču } 1 .\end{array}$ & 571 & 0.31 & 22.04 & 4627 & 13.85 & 2328 \\
\hline Variance within the board $s_{w j}^{2} /$ Varijanca unutar ploče & 334.232 & 0.001 & 3.811 & 289611.868 & 1.694 & 7176.817 \\
\hline $\begin{array}{l}\text { OSB No.2 } \\
\text { Average value within the board } \bar{x}_{j} \\
\text { Srednja vrijednost za ploču } 2 .\end{array}$ & 580 & 0.30 & 23.73 & 4864 & 14.21 & 2396 \\
\hline Variance within the board $s_{w j}^{2}$ / Varijanca unutar ploče & 535.787 & 0.003 & 39.873 & 1154673.544 & 4.495 & 22850.805 \\
\hline $\begin{array}{l}\text { OSB No.3 } \\
\text { Average value within the board } \bar{x}_{j} \\
\text { Srednja vrijednost za ploču } 3 .\end{array}$ & 572 & 0.31 & 25.01 & 4971 & 12.14 & 1984 \\
\hline Variance within the board $s_{w j}^{2}$ / Varijanca unutar ploče & 806.876 & 0.001 & 13.886 & 499806.464 & 0.888 & 38764.905 \\
\hline Total average value $\overline{\bar{x}}$ / Ukupna srednja vrijednost & 575 & 0.31 & 23.62 & 4821 & 13.40 & 2236 \\
\hline $\begin{array}{l}\text { Variance of average values within the board s OSB } \\
1-3 s_{-}^{2} \\
\text { Varijanca srednje vrijednosti za ploče OSB } 1-3 \text {. }\end{array}$ & 27.539 & 0.00008 & 1.991 & 31015.143 & 1.220 & 48766.625 \\
\hline $\begin{array}{l}\text { Average value of variance values within the boards } \\
\text { OSB } 1-3 \bar{s}_{w}^{2} \\
\text { Srednja vrijednost varijanci za ploče OSB } 1-3 \text {. }\end{array}$ & 558.965 & 0.002 & 19.190 & 648030.626 & 2.359 & 22930.842 \\
\hline
\end{tabular}

Legend / Legenda: MOR - Bending strength / savojna čvrstoća; MOE - Modulus of elasticity / modul elastičnosti; $\sigma_{\mathrm{t}}$ - Tensile strength perpendicular / vlačna čvrstoća okomito

dicular to the board plane meet the requirements of the ČSN EN 300 Standard, viz. $0.32 \mathrm{~N} / \mathrm{mm}^{2}$.

The highest mean value of the bending strength in the main axis was determined in variant OSB 1.1 $\left(23.62 \mathrm{~N} / \mathrm{mm}^{2}\right)$ and the lowest mean values were measured in variant ECO $2.1\left(21.12 \mathrm{~N} / \mathrm{mm}^{2}\right)$. The ČSN EN 300 Standard requirement for this property is $\geq 20 \mathrm{~N} /$ $\mathrm{mm}^{2}$. Hence, satisfactory values were achieved in all variants. The highest mean value of the bending strength in the secondary axis was determined in variant ECO $2.2\left(14.70 \mathrm{~N} / \mathrm{mm}^{2}\right)$ and the lowest mean value in variant OSB $1.2\left(12.74 \mathrm{~N} / \mathrm{mm}^{2}\right)$. The ČSN EN 300 Standard requirement for this property is $\geq 10 \mathrm{~N} / \mathrm{mm}^{2}$. Hence, satisfactory values were achieved in all variants.

The highest determined mean value of the modulus of elasticity in the main axis was found with OSB $1.3\left(4956 \mathrm{~N} / \mathrm{mm}^{2}\right)$ and the lowest mean value in variant ECO $2.2\left(4754 \mathrm{~N} / \mathrm{mm}^{2}\right)$. The ČSN EN 300 Standard requirement for this property is $\geq 3500 \mathrm{~N} / \mathrm{mm}^{2}$. Consequently, satisfactory values were achieved in all variants.

Table 13 Statistical evaluation for variant 1.2, OSB/3, $18 \mathrm{~mm}$ nominal thickness

Tablica 13. Statistička procjena rezultata za varijantu 1.2, OSB/3 nominalne debljine $18 \mathrm{~mm}$

\begin{tabular}{|c|c|c|c|c|c|c|}
\hline $\begin{array}{l}\text { Variant } 1.2 \text { / Varijanta } 1.2 . \\
\text { Gradual press opening } \\
\text { Postupno otvaranje preše }\end{array}$ & $\begin{array}{l}\text { Density } \\
\text { Gustoća } \\
\mathrm{kg} / \mathrm{m}^{3}\end{array}$ & $\begin{array}{c}\boldsymbol{\sigma}_{\mathbf{t}^{\perp}} \\
\mathrm{N} / \mathrm{mm}^{2}\end{array}$ & $\begin{array}{l}\text { MOR } \| \\
\mathrm{N} / \mathrm{mm}^{2}\end{array}$ & $\begin{array}{l}\text { MOE } \| \\
\mathrm{N} / \mathrm{mm}^{2}\end{array}$ & $\begin{array}{l}\text { MOR } \perp \\
\mathrm{N} / \mathrm{mm}^{2}\end{array}$ & $\begin{array}{l}\text { MOE } \perp \\
\mathrm{N} / \mathrm{mm}^{2}\end{array}$ \\
\hline $\begin{array}{l}\text { OSB No.1 } \\
\text { Average value within the board } \bar{x}_{j} \\
\text { Srednja vrijednost za ploču } 1 . \\
\text { Variance within the board } s_{w j}^{2} \text { / Varijanca unutar ploče }\end{array}$ & $\begin{array}{c}575 \\
588.467\end{array}$ & 0.008 & 21.96 & $\begin{array}{r}4886 \\
51934.749\end{array}$ & 4.515 & $\begin{array}{c}2330 \\
30658.713\end{array}$ \\
\hline $\begin{array}{l}\text { OSB No.2 } \\
\text { Average value within the board } \bar{x}_{j} \\
\text { Srednja vrijednost za ploču } 2 \text {. } \\
\text { Variance within the board } s_{w j}^{2} \text { / Varijanca unutar ploče }\end{array}$ & 216.046 & 0.39 & $\begin{array}{r}24.02 \\
11 * .032\end{array}$ & $\begin{array}{c}4825 \\
282853.177\end{array}$ & $\begin{array}{l}12.36 \\
1.119\end{array}$ & $\begin{array}{c}2018 \\
29063.316\end{array}$ \\
\hline $\begin{array}{l}\text { OSB No.3 } \\
\text { Average value within the board } \bar{x}_{j} \\
\text { Srednja vrijednost za ploču } 3 \text {. } \\
\text { Variance within the board } s_{w j}^{2} / \text { Varijanca unutar ploče }\end{array}$ & $\begin{array}{c}572 \\
219.775\end{array}$ & $\begin{array}{l}0.36 \\
0.005\end{array}$ & $\begin{array}{l}23.92 \\
38.988\end{array}$ & $\begin{array}{c}5048 \\
373282.153\end{array}$ & $\begin{array}{l}12.30 \\
3.295\end{array}$ & $\begin{aligned} 2140 \\
77016.000\end{aligned}$ \\
\hline Total average value $\overline{\bar{x}}$ / Ukupna srednja vrijednost & 574 & 0.38 & 23.30 & 4920 & 12.74 & 2163 \\
\hline $\begin{array}{l}\text { Variance of average values within the board s OSB } 1-3 \\
s_{\frac{2}{2}}^{2} \text { / Varijanca srednje vrijednosti za ploče OSB } 1-3 \text {. }\end{array}$ & 3.634 & 0.00026 & 1.462 & 13235.755 & 0.492 & 24666.315 \\
\hline $\begin{array}{l}\text { Average value of variance values within the boards } \\
\text { OSB } 1-3 \bar{S}_{w}^{2} \\
\text { Srednja vrijednost varijanci za ploče OSB } 1-3 \text {. }\end{array}$ & 341.429 & 0.005 & 17.862 & 236023.359 & 2.976 & 45579.343 \\
\hline
\end{tabular}


Table 14 Statistical evaluation for variant 1.3, OSB/3, $18 \mathrm{~mm}$ nominal thickness

Tablica 14. Statistička procjena rezultata za varijantu 1.3, OSB/3 nominalne debljine $18 \mathrm{~mm}$

\begin{tabular}{|c|c|c|c|c|c|c|}
\hline $\begin{array}{l}\text { Variant } 1.3 \text { / Varijanta } 1.3 . \\
\text { Highly gradual press opening } \\
\text { Vrlo postupno otvaranje preše }\end{array}$ & $\begin{array}{l}\text { Density } \\
\text { Gustoća } \\
\mathrm{kg} / \mathrm{m}^{3}\end{array}$ & $\begin{array}{c}\boldsymbol{\sigma}_{\boldsymbol{t}^{\perp}} \\
\mathrm{N} / \mathrm{mm}^{2}\end{array}$ & $\begin{array}{l}\text { MOR } \| \\
\text { N/mm }{ }^{2}\end{array}$ & $\begin{array}{l}\text { MOE } \| \\
\mathrm{N} / \mathrm{mm}^{2}\end{array}$ & $\begin{array}{l}\text { MOR } \perp \\
\text { N/mm }\end{array}$ & $\begin{array}{l}\text { MOE } \perp \\
\text { N/mm² }\end{array}$ \\
\hline $\begin{array}{l}\text { OSB No.1 } \\
\text { Average value within the board } \bar{x}_{j} \\
\text { Srednja vrijednost za ploču } 1 . \\
\text { Variance within the board } s_{w j}^{2} \text { / Varijanca unutar ploče }\end{array}$ & $\begin{array}{c}579 \\
668.390\end{array}$ & $\begin{array}{l}0.41 \\
0.004\end{array}$ & $\begin{array}{l}22.52 \\
10.526\end{array}$ & $\begin{array}{c}4938 \\
213257.723\end{array}$ & $\begin{array}{l}12.76 \\
1.424\end{array}$ & $\begin{array}{c}2336 \\
15029.237\end{array}$ \\
\hline $\begin{array}{l}\text { OSB No.2 } \\
\text { Average value within the board } \bar{x}_{j} \\
\text { Srednja vrijednost za ploču } 2 . \\
\text { Variance within the board } s_{w j}^{2} / \text { Varijanca unutar ploče }\end{array}$ & $\begin{array}{c}578 \\
444.462\end{array}$ & 0.004 & $\begin{array}{r}23.90 \\
10.254\end{array}$ & $\begin{array}{c}4973 \\
267188.534\end{array}$ & $\begin{array}{l}14.01 \\
0.538\end{array}$ & $\begin{array}{c}2313 \\
28779.073\end{array}$ \\
\hline $\begin{array}{l}\text { OSB No.3 } \\
\text { Average value within the board } \bar{x}_{j} \\
\text { Srednja vrijednost za ploču } 3 . \\
\text { Variance within the board } s_{w i}^{2} / \text { Varijanca unutar ploče }\end{array}$ & 78.012 & 0.37 & $\begin{array}{l}21.85 \\
18.062\end{array}$ & 713755.949 & $\begin{array}{l}12.89 \\
3.154\end{array}$ & $\begin{aligned} 2244 \\
54230.130\end{aligned}$ \\
\hline Total average value $\overline{\bar{x}}$ / Ukupna srednja vrijednost & 576 & 0.37 & 22.76 & 4956 & 13.22 & 2298 \\
\hline $\begin{array}{l}\text { Variance of average values within the board s OSB 1-3 } \\
s_{w j}^{2} / \text { Varijanca srednje vrijednosti za ploče OSB } 1-3 .\end{array}$ & 18.830 & 0.001 & 0.230 & 306.753 & 0.468 & 2304.553 \\
\hline $\begin{array}{l}\text { Average value of variance values within the boards OSB } \\
1-3 \bar{s}_{w}^{2} / \text { Srednja vrijednost varijanci za ploče OSB } 1-3 \text {. }\end{array}$ & 396.955 & 0.004 & 12.947 & 398067.402 & 1.705 & 32679.480 \\
\hline
\end{tabular}

The highest mean value of the modulus of elasticity in the secondary axis was found in variant ECO $2.2\left(2378 \mathrm{~N} / \mathrm{mm}^{2}\right)$ and the lowest mean value on average in variant OSB $1.2\left(2163 \mathrm{~N} / \mathrm{mm}^{2}\right)$. The ČSN EN 300 Standard requirement for this property is $\geq 1400$ $\mathrm{N} / \mathrm{mm}^{2}$. Hence, satisfactory values were achieved in all variants.

We believe that the possible reasons for the lower values of tensile strength perpendicular to board plane in variant 1.1 and higher number of cracks are caused by compressing of chip mats resulting in inner elastic forces. The size of these forces depend strongly on the morphological size of the characteristic parameters of chips, fractions, tree species, moisture, temperature, specific compression pressure and possibly of compression speed. The coherence of boards for venting and discharge of the press is based on the cohesion of gluing bridges that are formed by pressing. The mat always finds places that are more compressed. In the finished boards this causes stress, which may result in springing. If this feedback springing is too big, its symptom is poor adhesion of chips. This can lead to the formation of thin zones. These loose zones indicate using of the wrong glue and may result in the rapid opening of the press caused by lower tensile strength perpendicular to board plane. The lower coherence of the pressed board is then reflected in a faster opening of the press.

Table 15 Statistical evaluation for variant 2.1, OSB/3 ECO, $18 \mathrm{~mm}$ nominal thickness

Tablica 15. Statistička procjena rezultata za varijantu 2.1, OSB/3 ECO nominalne debljine $18 \mathrm{~mm}$

\begin{tabular}{|c|c|c|c|c|c|c|}
\hline $\begin{array}{l}\text { Variant } 2.1 \text { / Varijanta } 2.1 . \\
\text { High-speed press opening } \\
\text { Vrlo brzo otvaranje preše }\end{array}$ & $\begin{array}{l}\text { Density } \\
\text { Gustoća } \\
\mathrm{kg} / \mathrm{m}^{3}\end{array}$ & $\begin{array}{c}\boldsymbol{\sigma}_{\mathbf{t}^{\perp}} \\
\mathrm{N} / \mathrm{mm}^{2}\end{array}$ & $\begin{array}{l}\text { MOR } \| \\
\mathrm{N} / \mathrm{mm}^{2}\end{array}$ & $\begin{array}{c}\text { MOE } \\
\mathrm{N} / \mathrm{mm}^{2}\end{array}$ & $\begin{array}{l}\text { MOR } \perp \\
\mathrm{N} / \mathrm{mm}^{2}\end{array}$ & $\begin{array}{l}\text { MOE } \perp \\
\mathrm{N} / \mathrm{mm}^{2}\end{array}$ \\
\hline $\begin{array}{l}\text { OSB No.1 } \\
\text { Average value within the board } \bar{x}_{j} \\
\text { Srednja vrijednost za ploču } 1 . \\
\text { Variance within the board } s_{w j}^{2} \text { / Varijanca unutar ploče }\end{array}$ & $\begin{array}{c}579 \\
257.277\end{array}$ & 0.003 & $\begin{array}{l}18.92 \\
7.194\end{array}$ & $\begin{array}{c}4535 \\
292168.325\end{array}$ & $\begin{array}{l}12.52 \\
5.543\end{array}$ & $\begin{aligned} 2159 \\
67091.186\end{aligned}$ \\
\hline $\begin{array}{l}\text { OSB No.2 } \\
\text { Average value within the board } \bar{x}_{j} \\
\text { Srednja vrijednost za ploču } 2 . \\
\text { Variance within the board } s_{w j}^{2} \text { / Varijanca unutar ploče }\end{array}$ & 253.923 & 0.36 & $\begin{array}{l}22.55 \\
21.075\end{array}$ & 916820.112 & $\begin{array}{l}13.18 \\
4.474\end{array}$ & $\begin{array}{r}2238 \\
66075,029\end{array}$ \\
\hline $\begin{array}{l}\text { OSB No.3 } \\
\text { Average value within the board } \bar{x}_{j} \\
\text { Srednja vrijednost za ploču } 3 \text {. } \\
\text { Variance within the board } s_{w j}^{2} / \text { Varijanca unutar ploče }\end{array}$ & $\begin{array}{c}581 \\
163.981\end{array}$ & 0.35 & $\begin{array}{l}21.90 \\
32.861\end{array}$ & $\begin{array}{c}5042 \\
609745.742\end{array}$ & $\begin{array}{l}15.55 \\
1.765\end{array}$ & $\begin{array}{r}2365 \\
9763.937\end{array}$ \\
\hline Total average value $\overline{\bar{x}}$ / Ukupna srednja vrijednost & 580 & 0.35 & 21.12 & 4775 & 13.75 & 2254 \\
\hline $\begin{array}{l}\text { Variance of average values within the board s OSB 1-3 } \\
S_{\frac{2}{x}} / \text { Varijanca srednje vrijednosti za ploče OSB } 1-3 .\end{array}$ & 1.237 & 0.00001 & 3.836 & 64750.495 & 2.529 & 10819.885 \\
\hline $\begin{array}{l}\text { Average value of variance values within the boards } \\
\text { OSB } 1-3 \bar{S}_{w}^{2} \\
\text { Srednja vrijednost varijanci za ploče OSB } 1-3 \text {. }\end{array}$ & 225.06 & 0.003 & 20.377 & 606244.726 & 3.928 & 47643.384 \\
\hline
\end{tabular}


Table 16 Statistical evaluation for variant 2.2, OSB/3 ECO $18 \mathrm{~mm}$ nominal thickness

Tablica 16. Statistička procjena rezultata za varijantu 2.2, OSB/3 ECO, nominalne debljine $18 \mathrm{~mm}$

\begin{tabular}{|c|c|c|c|c|c|c|}
\hline $\begin{array}{l}\text { Variant } 2.2 \text { / Varijanta } 1.2 . \\
\text { Gradual press opening } \\
\text { Postupno otvaranje preše }\end{array}$ & $\begin{array}{l}\text { Density } \\
\text { Gustoća } \\
\mathrm{kg} / \mathrm{m}^{3}\end{array}$ & $\begin{array}{c}\boldsymbol{\sigma}_{\mathrm{t}^{\perp}} \\
\mathrm{N} / \mathrm{mm}^{2}\end{array}$ & $\begin{array}{l}\text { MOR } \| \\
\mathrm{N} / \mathrm{mm}^{2}\end{array}$ & $\underset{\mathrm{N} / \mathrm{mm}^{2}}{\text { MOE }}$ & $\begin{array}{c}\mathrm{MOR} \perp \\
\mathrm{N} / \mathrm{mm}^{2}\end{array}$ & $\begin{array}{l}\mathrm{MOE} \perp \\
\mathrm{N} / \mathrm{mm}^{2}\end{array}$ \\
\hline $\begin{array}{l}\text { OSB No.1 } \\
\text { Average value within the board } \bar{x}_{j} \\
\text { Srednja vrijednost za ploču } 1 .\end{array}$ & 577 & 0.35 & 23.38 & 4555 & 15.94 & 2686 \\
\hline Variance within the board $s_{w j}^{2}$ / Varijanca unutar ploče & 365.180 & 0.004 & 33.571 & 1149041.76 & 12.414 & 1059144.972 \\
\hline $\begin{array}{l}\text { OSB No.2 } \\
\text { Average value within the board } \bar{x}_{j} \\
\text { Srednja vrijednost za ploču } 2 .\end{array}$ & 588 & 0.32 & 22.31 & 4937 & 14.39 & 2240 \\
\hline Variance within the board $s_{w j}^{2}$ / Varijanca unutar ploče & 168.308 & 0.003 & 32.296 & 675353.939 & 0.684 & 40808.001 \\
\hline $\begin{array}{l}\text { OSB No.3 } \\
\text { Average value within the board } \bar{x}_{j} \\
\text { Srednja vrijednost za ploču } 3 .\end{array}$ & 574 & 0.38 & 22.62 & 4769 & 13.77 & 2208 \\
\hline Variance within the board $s_{w j}^{2}$ / Varijanca unutar plocee & 251.575 & 0.004 & 25.026 & 516186.162 & 2.200 & 22819.537 \\
\hline Total average value $\overline{\bar{x}}$ / Ukupna srednja vrijednost & 580 & 0.35 & 22.77 & 4754 & 14.70 & 2378 \\
\hline $\begin{array}{l}\text { Variance of average values within the board s OSB 1- } \\
3 s_{x}^{2} / \text { Varijanca srednje vrijednosti za ploče OSB 1-3. }\end{array}$ & 48.728 & 0.0009 & 0.219 & 36648.388 & 1.252 & 71144.966 \\
\hline $\begin{array}{l}\text { Average value of variance values within the boards } \\
\text { OSB } 1-3 \bar{s}_{w}^{2} \\
\text { Srednja vrijednost varijanci za ploče OSB } 1-3 \text {. }\end{array}$ & 261.688 & 0.004 & 30.297 & 780193.953 & 5.100 & 374257.503 \\
\hline
\end{tabular}

\section{CONCLUSSION}

4. ZAKLJUČCl

The aim of this paper was to optimize a pressing diagram on the basis of measuring changes of pressure and temperature in the board in the course of pressing. Changes of the pressing diagram were carried out at the stage of "press opening" because these changes substantially affected physical and mechanical properties of OSB boards. For each change of "press opening" three boards were sampled and used to cut test samples. With these specimens, the following parameters were determined: density, tensile strength perpendicular to the board plane, bending strength and the mo- dulus of elasticity in bending in the main and secondary axes of production.

In variant 1.1 (very fast "press opening"), the unsatisfactory mean value of tensile strength perpendicular to the board plane was detected, exactly $0.31 \mathrm{~N} /$ $\mathrm{mm}^{2}$. In this variant, increased formation of vapour "blisters" and cracking of the boards occurred due to very fast cooling and outflow of water vapours after shortening the process to the required time, namely about $5 \%$ of OSB production. So, this variant is unusable in production since it is impossible to achieve the required values of tensile strength perpendicular to the board plane as well as due to the large number of wasters. According to the measured laboratory results, the

Table 17 Statistical evaluation for variant 2.3, OSB/3 ECO, $18 \mathrm{~mm}$ nominal thickness

Tablica 17. Statistička procjena rezultata za varijantu 2.3, OSB/3 ECO nominalne debljine $18 \mathrm{~mm}$

\begin{tabular}{|c|c|c|c|c|c|c|}
\hline $\begin{array}{l}\text { Variant } 2.3 \text { / Varijanta } 1.3 . \\
\text { High gradual press opening } \\
\text { Vrlo postupno otvaranje preše }\end{array}$ & $\begin{array}{c}\text { Density } \\
\text { Gustoća } \\
\mathrm{kg} / \mathrm{m}^{3}\end{array}$ & $\begin{array}{c}\boldsymbol{\sigma}_{\mathbf{t}^{\perp}} \\
\mathrm{N} / \mathrm{mm}^{2}\end{array}$ & $\begin{array}{l}\text { MOR } \| \\
\text { N/mm }\end{array}$ & $\begin{array}{l}\text { MOE } \| \\
\mathrm{N} / \mathrm{mm}^{2}\end{array}$ & $\begin{array}{l}\text { MOR } \perp \\
\mathrm{N} / \mathrm{mm}^{2}\end{array}$ & $\begin{array}{l}\text { MOE } \perp \\
\text { N/mm }\end{array}$ \\
\hline $\begin{array}{l}\text { OSB No.1 } \\
\text { Average value within the board } \bar{x}_{j} \\
\text { Srednja vrijednost za ploču } 1 . \\
\text { Variance within the board } s_{w j}^{2} / \text { Varijanca unutar ploče }\end{array}$ & 329.134 & 0.004 & 16.347 & 403166.399 & 2.677 & $\begin{array}{c}2304 \\
30532.841\end{array}$ \\
\hline $\begin{array}{l}\text { OSB No.2 } \\
\text { Average value within the board } \bar{x}_{j} \\
\text { Srednja vrijednost za ploču } 2 . \\
\text { Variance within the board } s_{w j}^{2} \text { / Varijanca unutar ploče }\end{array}$ & $\begin{array}{c}581 \\
207.691\end{array}$ & $\begin{array}{l}0.38 \\
0.006\end{array}$ & $\begin{array}{r}23.45 \\
15.493\end{array}$ & $\begin{array}{c}4535 \\
1431889.08\end{array}$ & $\begin{array}{l}13.02 \\
1.080\end{array}$ & $\begin{array}{c}2138 \\
19486.849\end{array}$ \\
\hline $\begin{array}{l}\text { OSB No.3 } \\
\text { Average value within the board } \bar{x}_{j} \\
\text { Srednja vrijednost za ploču } 3 \text {. } \\
\text { Variance within the board } s_{w j}^{2} / \text { Varijanca unutar ploče }\end{array}$ & $\begin{array}{c}574 \\
110.865\end{array}$ & 0.004 & $\begin{array}{r}23.34 \\
21.026\end{array}$ & $\begin{array}{c}5100 \\
604861.700\end{array}$ & $\begin{array}{l}13.26 \\
0.217\end{array}$ & $\begin{array}{c}2134 \\
18594.528\end{array}$ \\
\hline Total average value $\overline{\bar{x}} /$ Ukupna srednja vrijednost & 577 & 0.36 & 22.61 & 4885 & 13.51 & 2192 \\
\hline $\begin{array}{l}\text { Variance of average values within the board s OSB 1-3 } \\
s_{\frac{2}{x}}^{2} \text { Varijanca srednje vrijednosti za ploče OSB } 1-3 \text {. }\end{array}$ & 11.971 & 0.0004 & 1.942 & 93612.425 & 0.431 & 9387.606 \\
\hline $\begin{array}{l}\text { Average value of variance values within the boards OSB } \\
1-3 \bar{s}_{w}^{2} / \text { Srednja vrijednost varijanci za ploče OSB } 1-3 \text {. }\end{array}$ & 215.897 & 0.005 & 17.622 & 813305.725 & 1.325 & 22871.406 \\
\hline
\end{tabular}


variant OSB/3 ECO, 2.2 gradual "press opening", was evaluated as optimal.

\section{Acknowledgement - Zahvala}

This paper was suported by the Czech Republic Ministry of Education, Youth and Sports, Project. No. MSM 6515648902

\section{REFERENCESS}

\section{LITERATURA}

1. Bolton, A.; Humphrey, P.; Kavvmouras, P., 1989: The hot pressing of the dry formed wood-based composites. Part IV. Predicted variation of mattress moisture content with time. Holzforschung 43 (5): 345-349. doi:10.1515/hfsg. 1989.43.5.345

2. Deppe, H. J.; Ernst, K., 1991: Taschenbuch der Spanplattentechnik. 3. überarbeitete und erweitete Auflage. DRW Verlag Leinfelden. 468 p.

3. Hrázský, J.; Král., P., 2007: Wood-based composites. Partt I.: Chips and fibrematerials. MZLU Brno. 253 p.

4. Kühne, G.; Belimow, F., 1978: Ein Beitrag zur Analyse des Heisspressvorgangs dreischichtiger Möbelplatten II. Holzindustrie (2): 50-52.

5. Štefka, V., 2007: Wood-based composites. Part II: Agglomerated materials technology. TU Zvolen. 204 p.
6. Štefka, V., 1999: Particleboard pressing process and transfer phenoma. TU Zvolen. 61 p.

7. $* * *$ CSN EN 300. OSB-panels of oriented flat chips. Definition, classification and requirements. Czech standard institution, 1998:20.

8. ${ }^{* * *}$ CSN EN 310 . Wood-based panels. Bending strength and modulus of elasticity determination. Czech standard institution, 1995:8.

9. $* * *$ CSN EN 319 . Chips- and fibreboards. Tensile strength perpendicular to the board surface determination. Czech standard institution, 1994:12.

10. $* *$ CSN EN 323 . Wood-based panels. Density determination. Czech standard institution, 1994:8.

\section{Corresponding address:}

Assistant Professor JAROSLAV HRÁZSKÝ, Ph.D.

Faculty of Forestry and Wood Technology

Mendel University

Zemědělská 1

61300 Brno

Czech Republic

e-mail: hrazsky@mendelu.cz 